\title{
Reindeer influence on ecosystem processes in the tundra
}

\author{
J. Olofsson, S. Stark and L. Oksanen
}

Olofsson, J., Stark, S. and Oksanen, L. 2004. Reindeer influence on ecosystem processes in the tundra. - Oikos 105: 386-396.

Reindeer have been recorded to increase nutrient cycling rate and primary production in studies from fences almost 40 years old that separate areas with different grazing regimes in northern Fennoscandia. To further understand the mechanism behind the effects of herbivores on primary production, we measured the size of the major $\mathrm{C}$ and $\mathrm{N}$ pools, soil temperature, litter decomposition rate and $\mathrm{N}$ mineralization rate in lightly, moderately and heavily grazed areas along two of these fences.

Plant $\mathrm{N}$ found in new biomass, indicative of plant $\mathrm{N}$ assimilation, was significantly higher in moderately and heavily grazed areas than in lightly grazed areas, which corresponded to a decreased amount of $\mathrm{N}$ in old plant parts. The amount of $\mathrm{N}$ found in plant litter or organic soil layer did not differ between the grazing treatments. Together with soil $\mathrm{N}$ concentrations and litter decomposition rates, soil temperatures were significantly higher in moderately and heavily grazed areas.

We conclude that the changes in soil temperature are important for the litter decomposition rate and thus on the nutrient availability for plant uptake. However, the changes in plant community composition appear to be more important for the altered $\mathrm{N}$ pools and thus the enhanced primary production. The results provide some support for the keystone herbivore hypothesis, which states that intensive grazing can promote a transition from moss-rich tundra heath to productive grasslands. Grazing altered N fluxes and pools, but the total N pools were similar in all grazing treatments. Our study thus indicates that grazing can increase the primary production through enhancing the soil nutrient cycling rate, even in a long term perspective on an ecological timescale.

J. Olofsson, and L. Oksanen, Dept of Ecology and Environmental Science, Umeå Univ., SE-90187 Umeå, Sweden (johan.olofsson@eg.umu.se). - S. Stark, Dept of Biology, Univ. of Oulu, P.O. Box 3000, FIN-90570 Oulu, Finland. Present address for SS: Rovaniemi Research Station, Finnish Forest Res. Inst., P.O. Box 16, FIN-96301 Rovaniemi, Finland.

By changing the quantity and quality of plant litter, by changing the soil microclimate for decomposition and mineralization processes, and by adding soluble $\mathrm{N}$ in the form of urine and faeces, herbivores often influence the rate of soil nitrogen $(\mathrm{N})$ cycling (Knapp and Seastedt 1986, Hobbie 1992, Hobbs 1996, Bardgett et al. 1998, Kielland and Bryant 1998). Nitrogen is the limiting factor for primary production in many terrestrial ecosystems (Chapin 1980, Vitousek and Howarth 1991), and grazer-mediated changes in the soil $\mathrm{N}$ cycling is therefore one of the mechanisms through which herbivores can influence plant productivity. Herbivory has been shown to sometimes enhance (McNaughton 1979, Cargill and Jefferies 1984, Pandey and Singh 1992, Frank and McNaughton 1993) and to sometimes retard (Pastor et al. 1993, Ritchie et al. 1998) the rate of soil nutrient cycling. The variation in the direction of the impact of herbivory appears to emerge from the fact that herbivores influence soil microbial processes through several different opposing mechanisms (Bardgett et al. 1998, Hobbs 1996). The net outcome of herbivory is therefore often determined by the balance between the strengths and directions of these mechanisms (Augustine and McNaughton 1998, Wardle et al. 2001).

Accepted 29 September 2003

Copyright (C) OIKOS 2004

ISSN 0030-1299 
The net effect of herbivory on nutrient cycling often varies over time because the strengths of the underlying mechanisms are changing. Kielland et al. (1997) reported that, in boreal forests, moose browsing results in opposite outcomes at different time scales. In the shortterm, browsing enhances litter decomposition and litter quality directly by increasing nutrient availability through urine and faeces, and by increasing the quality of the plant tissue of browsed plants (Kielland et al. 1997, Kielland and Bryant 1998). In the long term, however, browsing retards litter decomposition, because moose feed selectively on plants that produce high quality litter, thus favoring species producing low-quality litter (McInnes et al. 1992, Pastor and Naiman 1992, Pastor et al. 1993). Sirotnak and Huntly (2000) found that voles enhanced soil nutrient cycling during their population peaks, but that mineralization rates were retarded over longer periods because vole herbivory decreased the abundance of plants that produce highquality litter. Thus, the role of different mechanisms the selective feeding of herbivores vs the direct influence of an $\mathrm{N}$ input through urine and faeces - varied according to the grazing intensity, thus causing temporal and spatial variation in the direction of the impact on soil nutrient cycling. It has also been hypothesized that the effects of herbivores differ over time, because the nutrient cycling rate is important for the short-time effects of herbivory, whereas long-term effects are mainly determined by the balance between nutrient inputs and losses (de Mazancourt et al. 1998).

Studies from fences more than 30 years old that separates summer and winter grazed areas, have shown that reindeer grazing can cause a shift in the tundra vegetation from a moss-rich heath into a grass dominated meadow (Olofsson et al. 2001). Heavy grazing by reindeer can increase soil nutrient availability (Olofsson et al. 2001, Stark et al. 2002, van der Wal and Brooker 2004, van der Wal et al. 2004) and plant primary productivity (Olofsson et al. 2001, Olofsson and Oksanen 2002). The shift in vegetation into more decomposable plant species may be an important mechanism underlying enhanced soil nutrient cycling rate (Olofsson and Oksanen 2002). However, we still do not know which of the proposed mechanisms that is most important. Moreover, even though increased soil temperatures are suggested to be important for the enhanced nutrient availability, the effect of herbivores on soil temperatures have not been measured in the Fennoscandian tundra. As the effects of reindeer grazing seem to be site-specific (Stark and Grellmann 2002, Stark et al. 2002), further understanding of these processes is essential to understand how the interactions between reindeer grazing, nutrient cycling and primary production differ between contrasting areas and timescales. To further understand the mechanisms behind the effect of reindeer on primary production, we measured the soil temperature and the size of all major ecosystem $\mathrm{C}$ and $\mathrm{N}$ pools and some central fluxes between them at eight sites along two different reindeer fences.

\section{Material and methods}

\section{Study area and design}

The study was carried out on two tundra heath areas in northern Norway. Cearro (location $69^{\circ} 40^{\prime} \mathrm{N}, 24^{\circ} 40^{\prime} \mathrm{E}$ ) is situated in the continental sector in Finnmark at $550 \mathrm{~m}$ a.s.l. (subsequently referred to as continental site). The dominating vegetation consists of lichen heaths of the Betula nana-Cladina type (Oksanen and Virtanen 1995). Raisduoddar (location $69^{\circ} 39^{\prime} \mathrm{N}, 27^{\circ} 30^{\prime} \mathrm{E}$ ) is situated in the sub-oceanic area in Troms between 600 and $700 \mathrm{~m}$ a.s.l. (subsequently referred to as sub-oceanic site). The predominating vegetation is heath of the Arctic Empetrum-Dicranum-Lichenes type (Oksanen and Virtanen 1995). Both study areas are bisected by a fence that was built in the 1960's to reduce the risk of reindeer illegally entering the migration areas or winter ranges during the summer. The fences are constructed of wire fixed onto $1-1.5 \mathrm{~m}$ high posts, and run for several kilometers over the tundra. At Cearro, the fence separates the summer ranges from the winter ranges. The winter grazed area is rather intensively used, but winter grazing has a less severe effect on the vegetation than summer grazing as snow protects it against trampling. At Raisduoddar, the fence separates the summer-ranges from areas grazed during the spring and autumn, but the spring- and autumn range near the fence is only lightly grazed (Olofsson et al. 2001). Both study areas lie about 100 $\mathrm{m}$ above the local timberline.

In both areas, the highest grazing intensities are encountered in a zone, about $50 \mathrm{~m}$ wide, adjacent to the fence on the summer range side, (subsequently referred to as the heavily grazed zone), while the area further away from the fence in the summer ranges is less intensively used (subsequently referred to as the moderately grazed zone). The effects of herbivory at different grazing intensities were studied by marking out 8 transects running parallel to the reindeer fence, spacing $100 \mathrm{~m}$, in areas where the tundra was uniform across the sites to minimize the effect of environmental factors other than herbivores. At each transect sampling plots were laid out $10 \mathrm{~m}$ from the fence in the lightly grazed area, $10 \mathrm{~m}$ from the fence in the heavily grazed area and $100 \mathrm{~m}$ from the fence in the moderately grazed area. As there only was one fence in each area, pseudoreplication can be an issue. However, as the minimal distance between transects are $100 \mathrm{~m}$, we believe that they can be regarded as independent of each other. 


\section{Reindeer activity}

Reindeer activity in each grazing treatment was monitored by means of trampling indicators (Bayfield 1971). We used nails with a $3-\mathrm{cm}$ long iron wire attached to the top. When the nail is pushed down into the soil the iron wire stands straight up, and bends if it is trampled on. Twenty-five trampling indicators were placed on 5 of the sampling plots in each treatment at both sites in July 2000 , and the number of indicators trampled on was recorded in July 2001.

\section{Plant biomass and productivity and $\mathrm{C}$ and $\mathrm{N}$ pools}

Aboveground biomass and new growth of plants were estimated by harvesting the standing crop in a $0.25 \mathrm{~m}^{2}$ large squares on each sampling plot at the peak of the growing season (end of July). The harvested material was sorted into plant species, and the current year shoots were visually separated from older tissue. As we did not measure radical growth of woody plant species, the new growth will be underestimated for those species (Shaver et al. 2001, Bret-Harte et al. 2002). Root and litter biomasses were estimated by taking soil cores (area 475.3 $\mathrm{cm}^{2}$ ) through the organic layer down into the mineral soil. Litter biomass was estimated by collecting all visible litter with tweezers. The root biomass was then determined by sorting out and washing all the roots. Mosses and lichens were harvested on $232.4 \mathrm{~cm}^{2}$ large circles. All plant samples were oven-dried $\left(60^{\circ} \mathrm{C}, 48 \mathrm{~h}\right)$ and weighed. Dry samples were then milled (Cyclotec 1093 Mill, FossTecator, Högnäs, Sweden) and analyzed for $\mathrm{C}$ and $\mathrm{N}$ on a CHNS-O analyzer (Fison's Instruments, Milan, Italy).

\section{Soil $\mathbf{N}$ and $\mathbf{C}$ pools and mineralization}

Composite soil samples consisting of 7 soil cores (each 3 $\mathrm{cm}$ diameter) extending down through the whole organic layer were taken from each sampling plot at the end of July in 2000 and 2001. The thickness of the organic layer was measured on each soil core. The samples were taken next to the area where the plant biomass was harvested. The fresh samples were homogenized by sieving (mesh $0.5 \mathrm{~cm}$ ), and a sub-sample was immediately put into polyethylene bags and replaced in the soil for measuring $\mathrm{N}$ mineralization (Eno 1960).

The rest of the soil sample was kept cool during transportation to the laboratory, and then frozen until analysis. Bulk density, moisture $\left(105^{\circ} \mathrm{C}, 12 \mathrm{~h}\right)$ and organic matter $(\mathrm{OM})$ content (aching at $475^{\circ} \mathrm{C}, 4 \mathrm{~h}$ ) were determined gravimetrically. A sub-sample of ca $6 \mathrm{~g}$ was extracted with $50 \mathrm{ml}$ of $0.5 \mathrm{M} \mathrm{K}_{2} \mathrm{SO}_{4}$ for determination of the extractable $\mathrm{N}$ concentration. The $\mathrm{NH}_{4}-\mathrm{N}$ concentration was determined by flow injection analysis (FIA Instruments). Total extractable $\mathrm{N}$ in the extracts was determined by oxidizing the entire extractable $\mathrm{N}$ to $\mathrm{NO}_{3}^{-}$(Williams et al. 1995), and then analyzing it as $\mathrm{NO}_{3}^{-}$by FIA. Extractable organic $\mathrm{N}$ was calculated as the difference between total extractable $\mathrm{N}$ and the extractable $\mathrm{NH}_{4}-\mathrm{N}$ concentrations. Microbial $\mathrm{N}$ was extracted from the samples using $0.5 \mathrm{M} \mathrm{K}_{2} \mathrm{SO}_{4}$ after chloroform fumigation (18 h, Brookes et al. 1985), and analyzed as total extractable $\mathrm{N}$ after oxidation as above. Microbial $\mathrm{N}$ was calculated by subtracting total extractable $\mathrm{N}$ in the unfumigated extracts from that in the fumigated ones.

\section{Litter decomposition}

On the 12 th of July 2000 , litter bags were placed in the same plots from which plant and soil samples were taken. Half of the litter bags (mesh $1.0 \mathrm{~mm}$ ) contained 1 $\mathrm{g}$ of oven-dry Deschampsia flexuosa (N 1.38\% of dry weight) and half of the litter bags $1 \mathrm{~g}$ of Vaccinium myrtillus leaves (N 1.35\% of dry weight), collected in Oulu, northern Finland. Both species are common at the two study sites. Bags were collected from the plots one year later, and the oven-dry weight $\left(60^{\circ} \mathrm{C}, 48 \mathrm{~h}\right)$ and $\mathrm{C}$ and $\mathrm{N}$ concentration (CHNS-O analyzer, Fison's Instruments, Milan, Italy) were determined. Net $\mathrm{C}$ and $\mathrm{N}$ loss from the bag was determined by subtracting the value for the $\mathrm{N}$ concentration $\times$ litter mass at sampling from that at the time of litterbag enplacement.

\section{Soil temperature}

The soil temperature was measured at $10 \mathrm{~cm}$ depth every hour between July 12th 2000 and July 15th 2001 by means of a Tinytag data logger with an external soil probe on three sampling plots in each treatment at both sites. However, as the data loggers in the continental site were stolen, the soil temperature is only reported from the suboceanic site.

\section{Statistical analyses}

The effect of grazing on plant and soil $\mathrm{C}$ and $\mathrm{N}$ pools and processes was tested with a one-way ANOVA. The $\mathrm{C}$ and $\mathrm{N}$ concentrations in the different plant growth forms were tested with a two-way ANOVA with plant growth form and grazing treatment as factors. The analysis was followed by the Tukey HSD test. Differences in the mean monthly temperature between the different grazing intensities in the suboceanic site were tested with a repeated-measure ANOVA, with grazing treatment as a between subject factor. This ANOVA procedure takes the correlation between the sampling dates into account. The length of time (in hours) that the soil temperature was above certain temperature limits was tested with a 
one-way ANOVA, with grazing treatment as dependent variable, followed by a Tukey HSD test. Interaction between the soil $\mathrm{N}$ concentration and mineralization and plant $\mathrm{N}$ uptake was analyzed by means of linear regression.

\section{Results}

\section{Reindeer activity}

The highest proportion of trampling indicators were trampled on in the zone near the fence, which we a priori expected to be the most heavily grazed both in the continental and in the sub-oceanic study site $(\mathrm{F}=997.0$, $\mathrm{P}<0.001 ; \mathrm{F}=283.9, \mathrm{P}<0.001$, Fig. 1), thus confirming the assumed difference in reindeer activity between the three grazing treatments. The proportion of activated trampling indicators did not appear to differ between the two areas.

\section{Ecosystem $\mathrm{C}$ and $\mathrm{N}$ pools}

Grazing did not affect the total ecosystem $\mathrm{N}$ pools $(\mathrm{F}=$ $1.37, \mathrm{P}=0.283 ; \mathrm{F}=0.41, \mathrm{P}=0.674$; Fig. 2 ) in either of the two study sites. Grazing reduced the total ecosystem $\mathrm{C}$ pool in the continental study site $(\mathrm{F}=6.17, \mathrm{P}=0.011$, Fig. 3) but not in the sub-oceanic study site $(\mathrm{F}=0.41$, $\mathrm{P}=0.674)$. The ecosystem $\mathrm{N}$ pool appeared to be larger in the sub-oceanic than in the continental study site (Fig. 2), but there was no difference in the total $\mathrm{C}$ pool (Fig. 3).

Although grazing had no effect on the total ecosystem $\mathrm{N}$ and $\mathrm{C}$ pools, the distribution of $\mathrm{N}$ and $\mathrm{C}$ between the different compartments in the ecosystem had changed considerably (Fig. 2, 3). The soil $\mathrm{N}$ pool was larger in the moderately and heavily grazed zones than in the lightly grazed zone in both study areas $(\mathrm{F}=7.42, \mathrm{P}=0.006$; $\mathrm{F}=6.63, \mathrm{P}=0.009)$. In the continental area, the soil $\mathrm{C}$ pool was significantly larger in the moderately grazed

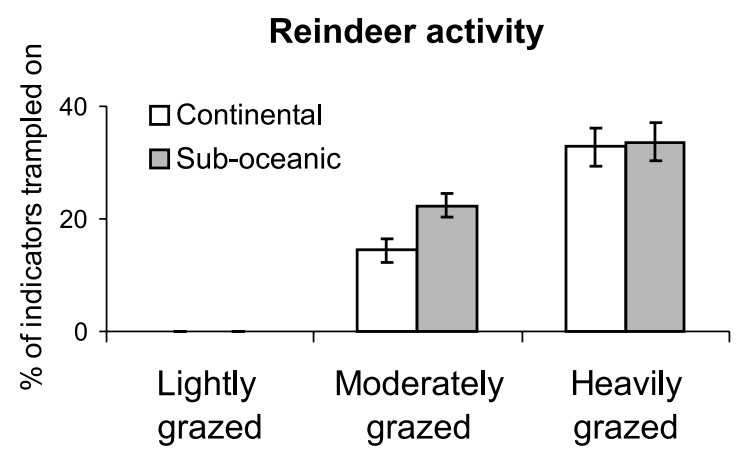

Fig. 1. Reindeer activity measured as $\%$ of trampling indicators triggered in the three grazing treatments in a continental and a suboceanic site (mean $\pm \mathrm{SE})$.

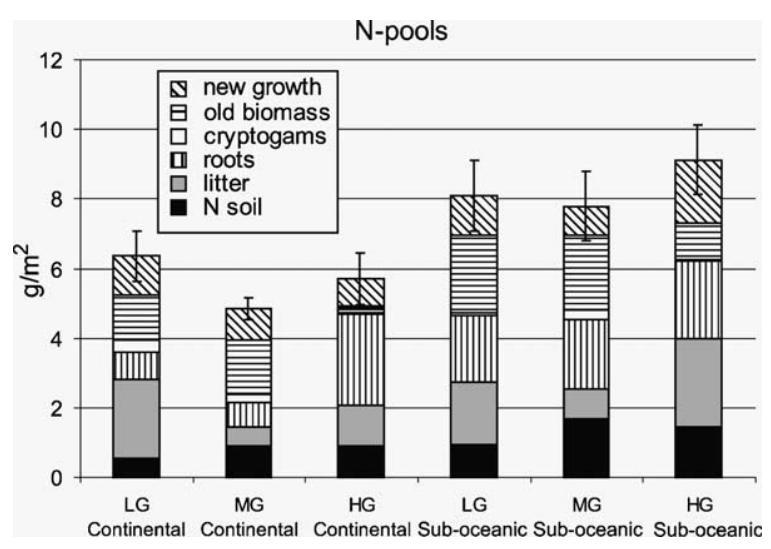

Fig. 2. Distribution of $\mathrm{N}$ among different pools in lightly grazed (LG), moderately grazed (MG) and heavily grazed areas $(\mathrm{HG})$ in a continental and in a suboceanic site (mean $\pm \mathrm{SE})$.

than in the lightly grazed area $(\mathrm{F}=6.12, \mathrm{P}=0.011)$, but there were no significant differences in the sub-oceanic area $(\mathrm{F}=1.01, \mathrm{P}=0.389)$.

Grazing did not affect the plant $\mathrm{C}$ and $\mathrm{N}$ in new growth, indicative of plant $\mathrm{N}$ and $\mathrm{C}$ assimilation in the continental site $(\mathrm{F}=1.500, \mathrm{P}=0.255 ; \mathrm{F}=1.874, \mathrm{P}=$ 0.166 ). However, there was significantly more $\mathrm{C}$ and $\mathrm{N}$ in new growth in the heavily grazed zone than in the moderately grazed zone in the sub-oceanic site $(\mathrm{F}=$ $5.936, \mathrm{P}=0.005$, Fig. 2 ; $\mathrm{F}=4.900, \mathrm{P}=0.012$ ). In contrast, the plant $\mathrm{N}$ and $\mathrm{C}$ pools in the belowground biomass were larger in the heavily grazed site in the continental area $(F=10.525, P=0.001)$, while no significant difference were found in the sub-oceanic site $(\mathrm{F}=0.121, \mathrm{P}=0.887)$.

\section{Plant $\mathrm{N}$ and $\mathrm{C}$ in new growth, and $\mathrm{N}$ and $\mathrm{C}$ pools in different plant growth forms}

Grazing substantially affected the plant $\mathrm{N}$ and $\mathrm{C}$ pools in different growth forms (Table 1, 2). There was significantly less $\mathrm{N}$ and $\mathrm{C}$ in the graminoids, and more

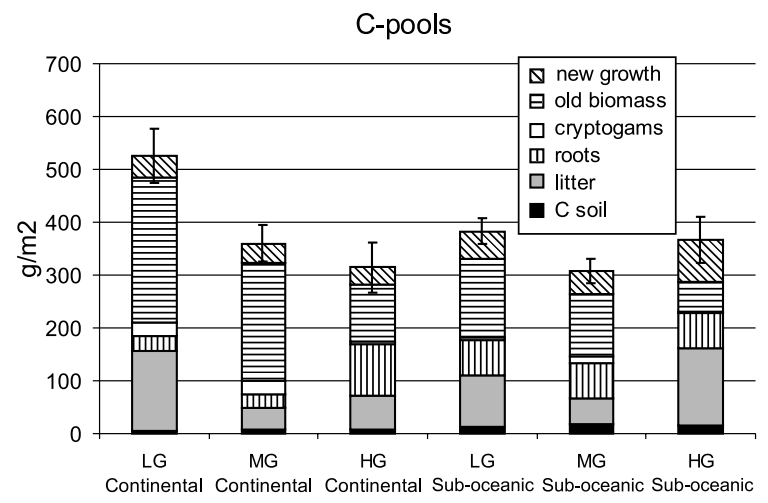

Fig. 3. Distribution of $\mathrm{C}$ among different pools in lightly grazed (LG), moderately grazed (MG) and heavily grazed areas (HG) in a continental and in a suboceanic site (mean $\pm \mathrm{SE})$. 
Table 1. The plant $\mathrm{N}$ pool in different growth forms in the continental area and in the suboceanic area in relation to reindeer grazing $(\mathrm{n}=8)$. Values are mean, and $\pm \mathrm{SE}$ in parentheses. The significance levels determined by ANOVA (NS not significant, ${ }^{*} \mathrm{P}<$ $0.05, * * \mathrm{P}<0.01, * * * \mathrm{P}<0.001)$.

\begin{tabular}{|c|c|c|c|c|c|}
\hline & & \multicolumn{4}{|l|}{$\mathrm{g} \mathrm{N} \mathrm{m}^{-2}$} \\
\hline & & Lightly grazed & Moderately grazed & Heavily grazed & \\
\hline \multicolumn{6}{|l|}{ Continental area } \\
\hline Graminoids & & $0.02^{\mathrm{a}}(0.01)$ & $0.03^{\mathrm{a}}(0.01)$ & $0.54^{\mathrm{b}}(0.15)$ & $* * *$ \\
\hline Herbs & & $0.002(0.002)$ & $0.001(0.001)$ & $0.001(0.001)$ & ns \\
\hline \multirow[t]{2}{*}{ Deciduous shrubs } & new growth & $1.05^{\mathrm{b}}(0.17)$ & $0.82^{\mathrm{a}}(0.14)$ & $0.26^{\mathrm{b}}(0.12)$ & $* *$ \\
\hline & old biomass & $1.16^{\mathrm{a}}(0.21)$ & $1.38^{\mathrm{a}}(0.24)$ & $0.18^{\mathrm{b}}(0.11)$ & $* * *$ \\
\hline \multirow[t]{2}{*}{ Evergreen shrubs } & new growth & $0.053(0.018)$ & $0.062(0.029)$ & $0.004(0.003)$ & ns \\
\hline & old biomass & $0.03(0.01)$ & $0.03(0.02)$ & $0.02(0.02)$ & ns \\
\hline Mosses & & $0.24(0.11)$ & $0.21(0.12)$ & $0.03(0.03)$ & ns \\
\hline Lichens & & $0.114(0.062)$ & $0.008(0.005)$ & $0.002(0.001)$ & ns \\
\hline \multicolumn{6}{|l|}{ Suboceanic area } \\
\hline Graminoids & & $0.03^{\mathrm{a}}(0.01)$ & $0.10^{\mathrm{b}}(0.03)$ & $1.08^{\mathrm{c}}(0.29)$ & $* * *$ \\
\hline Herbs & & $0.01(0.01)$ & $0.04(0.04)$ & $0.09(0.05)$ & ns \\
\hline \multirow[t]{2}{*}{ Deciduous shrubs } & new growth & $0.86(0.15)$ & $0.22(0.07)$ & $0.50(0.22)$ & ns \\
\hline & old biomass & $1.56^{\mathrm{a}}(0.61)$ & $0.83^{\mathrm{ab}}(0.23)$ & $0.48(0.35)^{\mathrm{b}}$ & $*$ \\
\hline \multirow[t]{2}{*}{ Evergreen shrubs } & new growth & $0.23(0.08)$ & $0.36(0.10)$ & $0.14(0.09)$ & ns \\
\hline & old biomass & $0.55(0.21)$ & $1.31(0.33)$ & $0.59(0.41)$ & ns \\
\hline Mosses & & $0.04(0.02)$ & $0.32(0.11)$ & $0.27(0.12)$ & ns \\
\hline Lichens & & - & - & - & \\
\hline
\end{tabular}

in the deciduous dwarf shrubs, in the moderately and lightly grazed zones than in the heavily grazed zones. The plant $\mathrm{N}$ pool in the new growth of deciduous shrubs differed significantly between the grazing intensities in the continental area, and a similar trend was also found in the sub-oceanic area (Table 1).

\section{Plant $\mathbf{N}$ concentrations}

The $\mathrm{N}$ concentration of the total plant biomass was significantly higher in the heavily grazed zones than in the moderately or lightly grazed zones in the conti- nental and the sub-oceanic site $(\mathrm{F}=4.835, \mathrm{P}=0.009$; $\mathrm{F}=10.55, \mathrm{P}=0.001)$. At the species level, most of the differences between the grazing intensities were not significant (Table 3). Plant $\mathrm{N}$ concentrations differed significantly between the different plant growth forms in the continental and the sub-oceanic site $(F=41.152$, $\mathrm{P}<0.001 ; 25.8, \mathrm{P}<0.001)$.

\section{Soil $\mathbf{N}$ pools}

The thickness of the humus layer was $1.0 \pm 0.2 \mathrm{~cm}$ in the lightly grazed zone, $1.8 \pm 0.2$ in the moderately grazed zone, and $2.0 \pm 0.2 \mathrm{~cm}$ in the heavily grazed zone in the

Table 2. The plant $\mathrm{C}$ pool in different growth forms in the continental area and in the suboceanic area in relation to reindeer grazing $(\mathrm{n}=8)$. Values are mean, and $\pm \mathrm{SE}$ in parentheses. The significance levels determined by ANOVA (ns not significant, $* P<0.05$, $* * \mathrm{P}<0.01, * * * \mathrm{P}<0.001)$

\begin{tabular}{|c|c|c|c|c|c|}
\hline & & \multicolumn{4}{|l|}{$\mathrm{g} \mathrm{C} \mathrm{m}^{-2}$} \\
\hline & & Lightly grazed & Moderately grazed & Heavily grazed & \\
\hline \multicolumn{6}{|l|}{ Continental area } \\
\hline Graminoids & & $0.5^{\mathrm{a}}(0.1)$ & $0.7^{\mathrm{a}}(0.2)$ & $11.0^{\mathrm{b}}(2.9)$ & $* * *$ \\
\hline Herbs & & $0.06(0.06)$ & $0.02(0.02)$ & $0.01(0.01)$ & ns \\
\hline \multirow[t]{2}{*}{ Deciduous shrubs } & new growth & $19.0^{\mathrm{a}}(3.0)$ & $15.4^{\mathrm{a}}(2.6)$ & $4.4^{\mathrm{b}}(2.0)$ & $* * *$ \\
\hline & old biomass & $89.3^{\mathrm{a}}(16.0)$ & $109.2^{\mathrm{a}}(18.4)$ & $13.8^{\mathrm{b}}(8.8)$ & $* * *$ \\
\hline \multirow[t]{2}{*}{ Evergreen shrubs } & new growth & $1.35(0.40)$ & $2.64(1.52)$ & $0.08(0.05)$ & ns \\
\hline & old biomass & $7.7(3.6)$ & $13.5(8.9)$ & $0.5(0.3)$ & ns \\
\hline Mosses & & $14.6(6.8)$ & $11.5(6.2)$ & $1.9(1.7)$ & ns \\
\hline Lichens & & $10.7(5.9)$ & $0.8(0.6)$ & $0.1(0.1)$ & ns \\
\hline \multicolumn{6}{|l|}{ Suboceanic area } \\
\hline Graminoids & & $0.6^{\mathrm{a}}(0.3)$ & $2.2^{\mathrm{a}}(0.7)$ & $22.3^{\mathrm{b}}(2.3)$ & $* * *$ \\
\hline Herbs & & $0.2(0.2)$ & $1.0(1.0)$ & $1.38(0.62)$ & ns \\
\hline \multirow{2}{*}{ Deciduous shrubs } & new growth & $19.3(3.0)$ & $7.2(1.6)$ & $9.8(4.0)$ & $*$ \\
\hline & old biomass & $102.6(26.1)$ & $30.7(7.2)$ & $20.5(14.6)$ & $* *$ \\
\hline \multirow{2}{*}{ Evergreen shrubs } & new growth & $6.3(2.2)$ & $10.7(2.6)$ & $4.3(2.7)$ & ns \\
\hline & old biomass & $46.3(14.3)$ & $88.8(21.5)$ & $36.5(25.6)$ & ns \\
\hline Mosses & & $2.2(1.3)$ & $11.3(4.2)$ & $11.3(4.9)$ & $\mathrm{ns}$ \\
\hline Lichens & & - & - & - & - \\
\hline
\end{tabular}


Table 3. The $\mathrm{N}$ concentrations of different growth forms in the continental area and the suboceanic area in relation to reindeer grazing $(\mathrm{n}=8)$. Values are mean, and $\pm \mathrm{SE}$ in parentheses. The significance levels determined by ANOVA (ns not significant, ${ }^{*} \mathrm{P}<$ $0.05, * * \mathrm{P}<0.01, * * * \mathrm{P}<0.001)$.

\begin{tabular}{|c|c|c|c|c|c|}
\hline & & \multicolumn{4}{|c|}{$\mathrm{N}$ concentration $(\%)$} \\
\hline & & Lightly grazed & Moderately grazed & Heavily grazed & \\
\hline \multicolumn{6}{|l|}{ Continental area } \\
\hline Graminoids & & $2.28(0.11)$ & $2.01(0.16)$ & $2.32(0.06)$ & ns \\
\hline Herbs & & $1.85(-)$ & $1.91(-)$ & $2.29(-)$ & ns \\
\hline \multirow[t]{2}{*}{ Deciduous shrubs } & new growth & $2.77(0.16)$ & $2.71(0.07)$ & $2.88(0.12)$ & ns \\
\hline & old biomass & $0.72(0.02)$ & $0.68(0.02)$ & $0.80(0.09)$ & ns \\
\hline \multirow[t]{2}{*}{ Evergreen shrubs } & new growth & $1.83(0.15)$ & $1.54(0.12)$ & $2.18(0.16)$ & $*$ \\
\hline & old biomass & $1.00(0.08)$ & $0.95(0.10)$ & $1.19(0.12)$ & ns \\
\hline Roots & & $1.19(0.06)$ & $1.32(0.10)$ & $1.31(0.07)$ & ns \\
\hline Mosses & & $0.77(0.06)$ & $0.81(0.09)$ & $0.84(0.12)$ & ns \\
\hline Lichens & & $0.49(0.02)$ & $0.54(0.10)$ & $0.69(0.15)$ & ns \\
\hline Litter & & $0.76(0.06)$ & $0.71(0.07)$ & $0.85(0.04)$ & ns \\
\hline \multicolumn{6}{|l|}{ Suboceanic area } \\
\hline Graminoids & & $1.92(0.06)$ & $2.15(0.06)$ & $2.28(0.13)$ & ns \\
\hline Herbs & & $2.54(-)$ & $2.42(0.47)$ & $2.50(0.25)$ & ns \\
\hline \multirow[t]{2}{*}{ Deciduous shrubs } & new growth & $2.2(0.1)$ & $2.4(0.2)$ & $2.3(0.2)$ & ns \\
\hline & old biomass & $0.9(0.1)$ & $1.5(0.3)$ & $1.2(0.1)$ & ns \\
\hline \multirow[t]{2}{*}{ Evergreen shrubs } & new growth & $1.8(0.1)$ & $1.7(0.2)$ & $1.7(0.2)$ & ns \\
\hline & old biomass & $0.78(0.03)$ & $0.9(0.1)$ & $1.0(0.11)$ & ns \\
\hline Roots & & $1.36(0.07)$ & $1.30(0.06)$ & $1.34(0.11)$ & ns \\
\hline Mosses & & $1.06(0.15)$ & $1.31(0.19)$ & $1.18(0.30)$ & ns \\
\hline Lichens & & - & - & - & \\
\hline Litter & & $0.81(0.06)$ & $0.89(0.06)$ & $0.77(0.05)$ & ns \\
\hline
\end{tabular}

continental area, and was significantly thicker in the heavily grazed than in the lightly grazed zone $(\mathrm{F}=6.1$, $P=0.008)$. In the sub-oceanic area, the thickness of the humus layer was $2.0 \pm 0.3 \mathrm{~cm}$ in the lightly grazed zone, $2.6 \pm 0.5$ in the moderately grazed zone, and $2.4 \pm 0.3 \mathrm{~cm}$ in the heavily grazed zone, but did not differ statistically between the grazing treatments. Soil moisture content was not affected by the grazing treatments: $0.38 \pm 0.03 \mathrm{~g}$ $\mathrm{H}_{2} \mathrm{O} \mathrm{g}{ }^{-1}$ fresh soil in the continental site, and $0.60 \pm$ $0.04 \mathrm{~g} \mathrm{H}_{2} \mathrm{O} \mathrm{g}^{-1}$ fresh soil in the sub-oceanic area.

Soil $\mathrm{NH}_{4}^{+}-\mathrm{N}$ concentrations and their pool, calculated on an $\mathrm{OM}$ basis, were significantly increased by grazing in both sub-continental $(\mathrm{F}=12.1, \mathrm{P}<0.001)$ and suboceanic $(\mathrm{F}=5.1, \mathrm{P}=0.016)$ area. The same was true also when the values were calculated on area basis. The soil $\mathrm{NH}_{4}^{+}-\mathrm{N}$ concentration was significantly higher in the heavily grazed zone than in the moderately and lightly grazed zone (Tukey HSD test). The extractable organic $\mathrm{N}$ concentration was not affected by grazing. In sub-oceanic area, microbial $\mathrm{N}$ was significantly increased by grazing in both $\mathrm{OM}(\mathrm{F}=20.3, \mathrm{P}<0.001)$ and area $(\mathrm{F}=7.5, \mathrm{P}=0.004)$ basis. In the subcontinental area, grazing increased microbial $\mathrm{N}$ only when expressed on area basis $(\mathrm{F}=4.0, \mathrm{P}=0.035)$. The microbial $\mathrm{C} / \mathrm{N}$ ratio was also significantly affected by grazing in the suboceanic area $(\mathrm{F}=5.5, \mathrm{P}=0.013)$, and it was significantly lower in the heavily grazed than in the lightly grazed zone (Tukey HSD test). The soil $\mathrm{C} / \mathrm{N}$ ratio was significantly lower in the heavily grazed zone in the sub-continental area $(\mathrm{F}=7.3, \mathrm{P}=0.004$, Table 4$)$, and was significantly higher in the lightly grazed zones than in the moderately and heavily grazed zones (Tukey HSD test). There was high variation in the rate of net $\mathrm{N}$ mineralization in both areas, which was positive in some study plots and negative in some, and grazing had no statistically significant impact (Table 4).

\section{Litter decomposition}

In the sub-continental site, grazing significantly enhanced the net $\mathrm{C}$ loss from the litter $(\mathrm{F}=8.1, \mathrm{P}=$ $0.004)$. Grazing did not affect the weight loss and net $\mathrm{N}$ loss, but did increase the $\mathrm{N}$ concentration of litter at the end of the experiment $(\mathrm{F}=4.2, \mathrm{P}=0.036)$. Accordingly, grazing tended to enhance the net $\mathrm{C}$ loss in the sub-oceanic area $(F=3.6, P=0.052)$ and to increase the weight loss $(\mathrm{F}=3.2, \mathrm{P}=0.067)$. $\mathrm{C}$ loss was significantly lower in the lightly grazed zones than in the moderately and heavily grazed zones (Tukey HSD test). In the continental site, dry weight loss $(\mathrm{F}=213.2, \mathrm{P}<0.001)$, $\mathrm{N}$ loss $(\mathrm{F}=207.5, \mathrm{P}<0.001)$ and $\mathrm{C}$ loss $(\mathrm{F}=107.2, \mathrm{P}<$ $0.001)$ were significantly higher in the $D$. flexuosa leaves than in the $V$. myrtillus leaves. The same was true also in the sub-oceanic area $(\mathrm{F}=296.3, \mathrm{P}<0.001$ for weight loss, $\mathrm{F}=273.0, \mathrm{P}<0.001$ for $\mathrm{N}$ loss, and $\mathrm{F}=118.0, \mathrm{P}<$ 0.001 for C loss, Table 5.

\section{Plant-soil interactions}

The plant $\mathrm{N}$ pool in current year shoots, indicative of $\mathrm{N}$ uptake by the aboveground plant biomass, was positively correlated with the $\mathrm{NH}_{4}-\mathrm{N}$ concentration in the soil in the heavily grazed zones in both areas $\left(\mathrm{R}^{2}=0.469\right.$, 
Table 4. The soil and microbial $\mathrm{N}$ pools in the continental area and in the suboceanic area in relation to reindeer grazing $(\mathrm{n}=8)$. Values are mean, and $\pm \mathrm{SE}$ in parentheses. The significance levels determined by ANOVA $\left(\right.$ ns not significant, ${ }^{*} \mathrm{P}<0.05$, $* * \mathrm{P}<0.01$, $* * * \mathrm{P}<0.001)$. EON = extractable organic nitrogen.

\begin{tabular}{|c|c|c|c|c|}
\hline & Lightly grazed & Moderately grazed & Heavily grazed & \\
\hline \multicolumn{5}{|l|}{ Continental area } \\
\hline \multirow{2}{*}{$\begin{array}{l}\mathrm{NH}_{4}^{+}\left(\mu \mathrm{g} \mathrm{g}^{-1} \mathrm{OM}\right) \\
\quad\left(\mu \mathrm{g} \mathrm{m}^{-2}\right)\end{array}$} & $139.5(20.2)$ & $154.0(24.4)$ & $262.0(10.3)$ & $* * *$ \\
\hline & $16.0(2.4)$ & $29.9(6.2)$ & $44.5(5.2)$ & $* *$ \\
\hline \multirow{2}{*}{$\begin{array}{l}\operatorname{EON}\left(\mu g^{-1} \mathrm{OM}\right) \\
\quad\left(\mu \mathrm{g} \mathrm{m}^{-2}\right)\end{array}$} & $318.2(32.0)$ & $305.7(36.5)$ & $301.4(19.1)$ & ns \\
\hline & $38.6(5.5)$ & $55.0(8.2)$ & $49.6(4.3)$ & ns \\
\hline \multirow{2}{*}{$\begin{array}{l}\text { Microbial N }\left(\mu \mathrm{g} \mathrm{g}^{-1} \mathrm{OM}\right) \\
\quad\left(\mu \mathrm{g} \mathrm{m}^{-2}\right)\end{array}$} & $511.0(31.4)$ & $500.7(41.9)$ & $567.3(13.2)$ & ns \\
\hline & $61.4(6.5)$ & $88.7(10.5)$ & $95.7(9.7)$ & $*$ \\
\hline \multirow[t]{2}{*}{ Total N (mg g $\left.{ }^{-1} \mathrm{OM}\right)$} & $4.31(0.21)$ & $4.82(0.23)$ & $5.30(0.12)$ & $* *$ \\
\hline & $0.56(0.10)$ & $0.90(0.12)$ & $0.90(0.11)$ & ns \\
\hline \multirow{2}{*}{$\begin{array}{l}\text { Mineralization }\left(\mu \mathrm{g} \mathrm{g}^{-1} \mathrm{OM} \mathrm{y}^{-1}\right) \\
\quad\left(\mu \mathrm{g} \mathrm{m}^{-2} \mathrm{y}^{-1}\right)\end{array}$} & $127.4(149.2)$ & $102.2(60.7)$ & $216.5(84.4)$ & ns \\
\hline & $26.4(28.2)$ & $20.7(13.0)$ & $43.7(20.6)$ & ns \\
\hline Microbial C/N & $5.1(0.4)$ & $5.4(0.9)$ & $4.4(0.2)$ & ns \\
\hline Soil C/N & $11.4(0.5)$ & $10.2(0.7)$ & $8.9(0.3)$ & $* *$ \\
\hline \multicolumn{5}{|l|}{ Suboceanic area } \\
\hline \multirow{2}{*}{$\begin{array}{l}\mathrm{NH}_{4}^{+}\left(\mu \mathrm{g} \mathrm{g}^{-1} \mathrm{OM}\right) \\
\quad\left(\mu \mathrm{g} \mathrm{m}^{-2}\right)\end{array}$} & $194.5(37.6)$ & $233.4(33.7)$ & $335.2(24.2)$ & $*$ \\
\hline & $38.2(6.7)$ & $78.4(17.9)$ & $87.0(10.5)$ & $*$ \\
\hline \multirow{2}{*}{$\begin{array}{l}\mathrm{EON}\left(\mu \mathrm{g} \mathrm{g}^{-1} \mathrm{OM}\right) \\
\quad\left(\mu \mathrm{g} \mathrm{m}^{-2}\right)\end{array}$} & $111.4(14.2)$ & $82.3(12.4)$ & $95.5(16.2)$ & ns \\
\hline & $23.7(4.4)$ & $28.0(8.4)$ & $23.4(3.4)$ & ns \\
\hline \multirow{2}{*}{$\begin{array}{l}\text { Microbial N }\left(\mu \mathrm{g} \mathrm{g}^{-1} \mathrm{OM}\right) \\
\quad\left(\mu \mathrm{g} \mathrm{m}^{-2}\right)\end{array}$} & $358.1(20.7)$ & $553.6(43.7)$ & $787.9(67.1)$ & $* * *$ \\
\hline & $83.5(14.7)$ & $176.3(28.9)$ & $201.2(22.1)$ & $* *$ \\
\hline \multirow{2}{*}{$\begin{array}{l}\left.\text { Total N (mg g }{ }^{-1} \mathrm{OM}\right) \\
\quad\left(\mathrm{mg} \mathrm{m}^{-2}\right)\end{array}$} & $4.22(0.27)$ & $4.87(0.23)$ & $5.36(0.18)$ & $* *$ \\
\hline & $0.94(0.15)$ & $1.69(0.40)$ & $1.45(0.21)$ & ns \\
\hline \multirow{2}{*}{$\begin{array}{l}\text { Mineralization }\left(\mu \mathrm{g} \mathrm{g}^{-1} \mathrm{OM}^{-1}\right) \\
\quad\left(\mu \mathrm{g} \mathrm{m}^{-2} \mathrm{y}^{-1}\right)\end{array}$} & $-99.6(46.4)$ & $-47.7(57.1)$ & $-192.9(30.6)$ & ns \\
\hline & $-24.4(8.2)$ & $-27.1(31.4)$ & $-42.7(9.3)$ & ns \\
\hline Microbial C/N & $6.6(0.9)$ & $4.5(0.4)$ & $3.7(0.4)$ & $*$ \\
\hline Soil C/N & $12.5(0.9)$ & $11.0(0.6)$ & $10.7(0.9)$ & ns \\
\hline
\end{tabular}

$\left.\mathrm{P}=0.036 ; \mathrm{R}^{2}=0.881, \mathrm{P}=0.001\right)$, and close to significant in the other two grazing treatments in the suboceanic area $\left(\mathrm{LG}, \mathrm{R}^{2}=470, \mathrm{P}=0.061 ; \mathrm{MG}, \mathrm{R}^{2}\right.$,
$\mathrm{P}=0.081$ ). There were, however, no significant correlations between net $\mathrm{N}$ mineralization and the plant $\mathrm{N}$ pool in the current year production of the plants.

Table 5. Decomposition of Vaccinium myrtillus and Deschampsia flexuosa leaves left to decompose in the field for one year in relation to reindeer grazing. Values are mean, and $\pm \mathrm{SE}$ in parentheses. The significance levels determined by ANOVA (ns not significant, $* \mathrm{P}<0.05, * * \mathrm{P}<0.01, * * * \mathrm{P}<0.001)$.

\begin{tabular}{|c|c|c|c|c|c|}
\hline Litter property & Species & Lightly grazed & Moderately grazed & Heavily grazed & \\
\hline $\begin{array}{l}\text { Continental area } \\
\text { Decomposition mass loss }\left(\% \mathrm{yr}^{-1}\right) \\
\text { Litter N content }(\%) \\
\left.\text { Net litter C loss (mg C g litter-1 } \mathrm{yr}^{-1}\right) \\
\left.\text { Net litter N loss (mg N g litter-1 } \mathrm{yr}^{-1}\right)\end{array}$ & V. myrtillus & $\begin{array}{r}67.0(0.7) \\
2.3(0.05) \\
325.3(3.9) \\
5.9(0.2)\end{array}$ & $\begin{array}{r}68.1(1.0) \\
2.2(0.07) \\
331.9(5.2) \\
6.3(0.2)\end{array}$ & $\begin{array}{r}70.0(1.4) \\
2.5(0.2) \\
346.2(2.6) \\
5.9(0.4)\end{array}$ & $\begin{array}{l}\text { ns } \\
\text { ns } \\
* \\
\text { ns }\end{array}$ \\
\hline $\begin{array}{l}\text { Decomposition mass loss }\left(\% \mathrm{yr}^{-1}\right) \\
\text { Litter N content }(\%) \\
\left.\text { Net litter C loss (mg C g litter-1 } \mathrm{yr}^{-1}\right) \\
\left.\text { Net litter } \mathrm{N} \text { loss (mg N g litter-1 } \mathrm{yr}^{-1}\right)\end{array}$ & D. flexuosa & $\begin{aligned} & 80.7(1.2) \\
& 2.3(0.03) \\
& 367.8(6.1) \\
& 9.4(0.3)\end{aligned}$ & $\begin{array}{r}80.3(0.8) \\
2.4(0.2) \\
365.7(4.8) \\
9.1(0.3)\end{array}$ & $\begin{array}{r}82.4(0.6) \\
2.7(0.03) \\
378.9(1.1) \\
9.0(0.1)\end{array}$ & $\begin{array}{l}\text { ns } \\
* \\
\text { ns } \\
\text { ns }\end{array}$ \\
\hline $\begin{array}{l}\text { Sub-oceanic area } \\
\text { Decomposition mass loss }\left(\% \mathrm{yr}^{-1}\right) \\
\text { Litter N content }(\%) \\
\left.\text { Net litter C loss (mg C g litter-1 } \mathrm{yr}^{-1}\right) \\
\left.\text { Net litter N loss (mg N g litter-1 } \mathrm{yr}^{-1}\right) \\
\text { Decomposition mass loss }\left(\% \mathrm{yr}^{-1}\right) \\
\text { Litter N content (\%) } \\
\left.\text { Net litter C loss (mg C g litter-1 } \mathrm{yr}^{-1}\right) \\
\left.\text { Net litter N loss (mg N g litter-1 } \mathrm{yr}^{-1}\right)\end{array}$ & V. myrtillus & $\begin{array}{r}69.0(0.3) \\
2.5(0.09) \\
335.4(1.3) \\
5.8(0.2) \\
84.5(0.8) \\
2.2(0.51) \\
385.8(3.3) \\
10.4(0.6)\end{array}$ & $\begin{array}{r}71.3(0.8) \\
2.9(0.09) \\
346.9(3.6) \\
5.2(0.3) \\
82.9(0.9) \\
2.5(0.06) \\
378.2(4.1) \\
9.5(0.2)\end{array}$ & $\begin{array}{c}71.9(1.5) \\
2.9(0.17) \\
351.1(7.1) \\
5.4(0.4) \\
86.0(0.7) \\
2.8(0.17) \\
393.3(3.8) \\
10.0(0.4)\end{array}$ & $\begin{array}{l}\text { ns } \\
\text { ns } \\
\text { ns } \\
\text { ns } \\
\text { ns } \\
\text { ns } \\
\text { ns } \\
\text { ns }\end{array}$ \\
\hline
\end{tabular}




\section{Soil temperature}

Grazing had no significant main effect on soil temperature $(F=0.649, P=0.649)$, showing that the mean soil temperature had not changed on a yearly basis. The soil temperature in the different grazing treatments, however, varied between the months (significant grazing $\times$ month interaction, $\mathrm{F}=4.833, \mathrm{P}=0.001)$. Temperature also varied according to the month $(\mathrm{F}=411.9, \mathrm{P}<0.001)$. Soil temperature was significantly higher in the moderately and heavily grazed zones than in the lightly grazed zone in July 2000 and in June and July 2001 (Fig. 4). However, soil temperature was significantly lower in the moderately grazed zone than in the lightly grazed zone in November and December 2000. Significantly more hours with a temperature higher than $9^{\circ} \mathrm{C}(\mathrm{F}=7.143$, $\mathrm{P}=0.026)$ and $12^{\circ} \mathrm{C}(\mathrm{F}=6.911, \mathrm{P}=0.028$, Fig. 4) were recorded in the moderately and heavily grazed zones than in the lightly grazed zone. There was no difference between the different grazing treatments with respect to the number of hours with a soil temperature above $0^{\circ} \mathrm{C}$ $(\mathrm{F}=1.036, \mathrm{P}=0.411), 3^{\circ} \mathrm{C}(\mathrm{F}=2.911, \mathrm{P}=0.131)$ or $6^{\circ} \mathrm{C}(\mathrm{F}=3.989, \mathrm{P}=0.079)$.

\section{Discussion}

In all grazing treatments, most of the ecosystem $\mathrm{N}$ (60 to $75 \%$ ) was found in living plants. Changes in plant species composition had thus a strong potential to directly influence the $\mathrm{N}$ fluxes in these systems. Grazing did not affect the proportion of ecosystem $\mathrm{N}$ that was found in
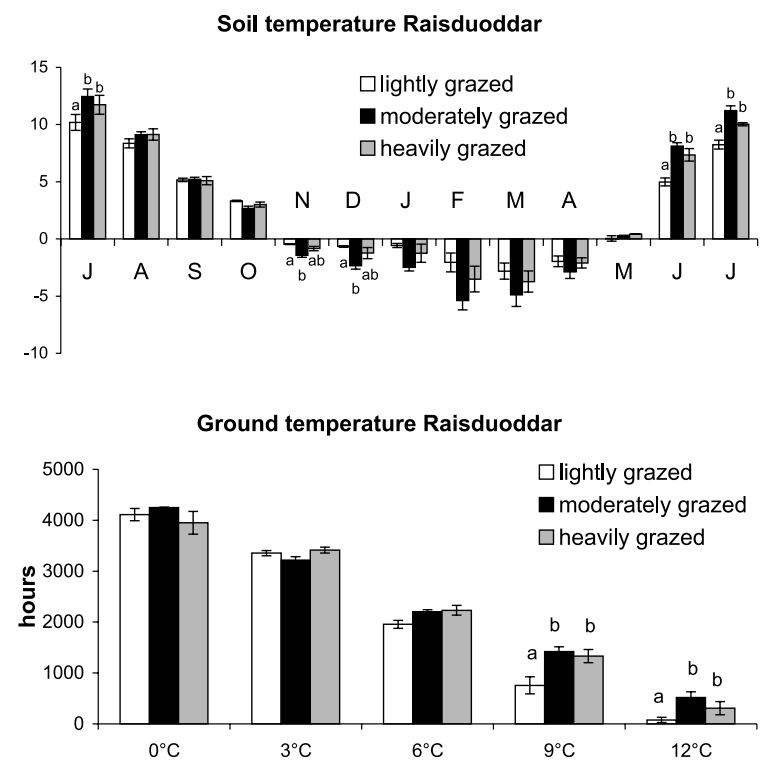

Fig. 4. Mean month soil temperature in the three different grazing treatments (mean $\pm \mathrm{SE}$ ) and the length of time (h) when the soil temperature was above $0^{\circ} \mathrm{C}, 3^{\circ} \mathrm{C}, 6^{\circ} \mathrm{C}, 9^{\circ} \mathrm{C}$ and $12^{\circ} \mathrm{C}$ $($ mean \pm SE). living plants, but there were considerable differences in the distribution of plant $\mathrm{N}$ in different compartments. In the lightly and moderately grazed areas, a large part of the $\mathrm{N}$ was found in old biomass, i.e. woody parts of dwarf shrubs and earlier produced evergreen leaves. In heavily grazed areas, the amount of $\mathrm{N}$ in old biomass had decreased and instead more $\mathrm{N}$ was found in the aboveground new growth in the sub-oceanic area and in roots in the continental area. Ecosystem $\mathrm{C}$ pools followed a trend similar to the $\mathrm{N}$ pools, but old biomass pool contained a larger proportion of the $\mathrm{C}$ than of the $\mathrm{N}$, and that the soil pool contained quite a substantial proportion of the $\mathrm{N}$, but only a very small fraction of the C. At the continental site, the soil $\mathrm{C}$ pool increased in the heavily grazed area, indicating that herbivory had a potential to increase the ecosystem pool of soil organic $\mathrm{C}$ (Molvar et al. 1993, Franzluebbers et al. 2000, Kryazhimskii and Danilov 2000). The role of mammalian herbivory for ecosystem $\mathrm{C}$ balances in the tundra, thus seriously need further investigation.

The larger new growth $\mathrm{C}$ and $\mathrm{N}$ pools in the suboceanic site and root $\mathrm{C}$ and $\mathrm{N}$ pools in the continental site indicate that grazing increased primary production in both areas, but the increased production was allocated above ground in the sub-oceanic area and belowground in the continental area. The root biomass is indicative of root production unless grazing considerably reduces the root biomass turnover (Milchunas and Laurenroth 1993). Hence, root production was probably enhanced by grazing in the continental site. We conclude that intense reindeer grazing increased plant growth in both study sites, but that the extra carbon thus acquired was allocated to different organs in different environments. The lower precipitation and nutrient availability in the continental site probably lead to lower intensity of shoot competition which, in combination with intense grazing, favours species with high root: shoot ratios (Carex bigelowii, Festuca ovina). In contrast, the dominating species of the sub-oceanic site (Anthoxantum odoratum, Calamagrostis lapponica) tend to allocate more resources to shoots.

In consistence with the earlier observations by Olofsson et al. (2001), Stark et al. (2002) and Olofsson and Oksanen (2002), reindeer grazing increased the litter decomposition rate and soil nutrient availability. Interestingly, although the net $\mathrm{C}$ loss rate from the litter was significantly enhanced in the moderately and heavily grazed areas, grazing did not affect the $\mathrm{N}$ loss, which could be due to a higher demand for $\mathrm{N}$ in relation to $\mathrm{C}$ by the soil microbes. The fact that there was no correlation between net $\mathrm{N}$ mineralization - which was negative at the sub-oceanic site - and plant $\mathrm{N}$ uptake to the aboveground biomass, indicates that measurement by the buried bag method did not reflect $\mathrm{N}$ availability for the plants. In a recent investigation by Schmidt et al. (2002), it was found that absence of plant roots in 
mineralization measurement seriously underestimates nutrient availability for plants. It has been proposed that the soluble organic $\mathrm{N}$ pool is more important for plants in arctic ecosystems (Chapin et al. 1993, Kielland 1994). However, we found a significant correlation between soil NH4-N concentration and plant $\mathrm{N}$ in the new growth, which support the conjecture that 1) inorganic $\mathrm{N}$ pool was a significant source for nutrients for plants, and 2) grazing enhanced plant productivity through enhancing the levels of inorganic N.

Our study also shows that the long-term effects of grazing in our study sites were substantially different from the short-term effects. In the continental site in 1973, 11 years after the establishment of the reindeer fence, dwarf shrubs had already been reduced to its current level, $9 \%$ in the heavily grazed area compared to $22 \%$ in the lightly grazed area, but the cover of graminoids in the heavily grazed area was only $6.9 \%$ compared to $3.6 \%$ in the lightly grazed area, and the biomass of graminoids was only 2.6 times higher in the heavily grazed area than in the lightly grazed area (Oksanen 1974, 1978). By contrast, 27 years later, the biomass of graminoids was 23.5 times higher in the heavily grazed area compared to the lightly grazed area. Relative to the quick destruction of the previous vegetation, expansion of graminoids was a slow process, taking several decades until they covered areas where dwarf shrubs had disappeared as a result of grazing. These results show that, to understand the role of herbivores in tundra ecosystems, studies in which grazing and trampling pressure have been manipulated for a very long time are required.

In the keystone herbivore hypothesis, Zimov et al. (1995) proposed that large mammals can shift the tundra to a graminoid-dominated "steppe stage". These changes in vegetation reduce soil moisture and increase the soil temperature, thus enhancing soil nutrient cycling and primary production. They hypothesized that climate alone does not explain the shift in the vegetation from steppe-like, productive grassland to unproductive tundra in Beringa in the end of Pleistocene. Instead, they proposed that the extinction of large mammals was the primary reason for these changes in the vegetation. According to their hypothesis, the grass-dominated "steppe stage" with high productivity and supporting high densities of herbivores is an alternative steady state for the moss-dominated tundra, even under current climatic conditions. This study, as well as previous studies from these fences (Olofsson et al. 2001, Olofsson and Oksanen 2002) shows that herbivores can cause the transition in vegetation similar to that proposed by Zimov et al. (1995) and increase soil temperature, thus enhancing ecosystem processes. However, the transition in vegetation only occurred in places with artificially high grazing pressure, and thus it is uncertain what kind of abundances of large herbivores the current vegetation could sustain in natural conditions.

According to the conjecture of de Mazancourt et al. (1998) and de Mazancourt and Loreau (2000), the processes discussed above should be unimportant for primary production in a state of equilibrium, when all the nutrient stocks and flows have reached a steady state. Their model demonstrated that nutrient turnover rates are important only for the transient dynamics of the system, whereas small differences in nutrient losses and inputs should determine the effect of herbivores on primary production in the long run (de Mazancourt et al. 1998, de Mazancourt and Loreau 2000). Even though we did not directly measure gains and losses from the system, we assumed that in case grazing had altered the balance between $\mathrm{N}$ input and output in the ecosystem, we would then detect a change in the total ecosystem $\mathrm{N}$. Although the fluxes and the distribution of $\mathrm{N}$ among the plant, soil and microbial pools were considerably altered 40 years after the construction of the reindeer fences, this had no detectable effect on the total ecosystem N. Hence, differences in $\mathrm{N}$ losses and gains must either be equal or differ so little that the system was equivalent to a chemostat, e.g. losses occurring at the same rate in all pools. In a chemostat and in closed systems, nutrient turnover rate should indeed increase primary production (Loreau 1995). We do not know whether our systems represented transient dynamics or steady-state system. Regardless of whether the heavily grazed tundra has reached equilibrium after 40 years or not, our study demonstrates that grazing can increase primary production without changing the total nutrient pool, even within a time frame that must be regarded as long on the ecological time scale.

Although summer grazing by reindeer has been found to enhance nutrient cycling and plant productivity, opposite outcome of grazing has been observed in an arctic tundra heath where herbivory mainly occurred during the winter (Grellmann 2002, Stark and Grellmann 2002). In this site, herbivores had a decelerating effect on soil nutrient cycling, which was related to the fact that deposition of mammalian waste products did not occur during the plant nutrient uptake, and urea and faeces deposited during the winter probably leached out from the system. Moreover, reindeer may export $\mathrm{N}$ during migration through their wintering grounds on their way to summer grounds (Stark and Grellmann 2002). Therefore, reindeer in tundra ecosystems of Fennoscandia may have mixed effects on nutrient cycling with varying positive or negative effects on ecosystem processes depending entirely on temporal and spatial patterns of the grazing. Reindeer grazing may therefore represent an intermediate case between a purely grazing and migratory system with enhanced rates of nutrient cycling (McNaughton 1979) and a non-migratory 
browsing system with decreased rates of nutrient cycling (Pastor et al. 1993).

Acknowledgements - We thank R. Bardgett, C. de Mazancourt, D. Grellmann, S. Jonasson, J. Pastor and J. Tuomi and for helpful comments on earlier versions of the manuscript. This study was supported by grants from The Swedish Natural Research Council to L.O., by grants from The Swedish Research Council for Environment, Agricultural Sciences and Spatial Planning and from Stiftelsen Oscar and Lili Lamms Minne to J. $\mathrm{O}$ and by grants from Maj and Tor Nessling Foundation to S. S.

\section{References}

Augustine, D. J. and McNaughton, S. J. 1998. Ungulate effects on the functional species composition of plant communities: herbivore selectivity and plant tolerance. - J. Wildl. Manage. 62: 1165-1183.

Bardgett, R., Keiller, S., Cool, R. E. D. et al. 1998. Dynamic interactions between soil fauna and microorganisms in upland grassland soils: a microcosm experiment. - Soil Biol. Biochem. 30: 531-539.

Bayfield, N. G. 1971. A simple method for detecting variations in walker pressure laterally across paths. - J. Appl. Ecol. 8: $533-535$.

Bret-Harte, M. S., Shaver, G. R. and Chapin III, F. S. 2002. Primary and secondary stem growth in arctic shrubs: implications for community responses to environmental change. - J. Ecol. 90: 251-267.

Brookes, P. C., Landman, A., Pruden, G. et al. 1985. Chloroform fumigation and release of soil nitrogen: a rapid direct extraction method to measure microbial biomass nitrogen in soils. - Soil Biol. Biochem. 17: 837-842.

Cargill, M. S. and Jefferies, R. L. 1984. The effects of grazing by lesser snow geese on the vegetation of a sub-arctic salt marsh. - J. Appl. Ecol. 21: 669-686.

Chapin, F. S. III. 1980. The mineral nutrition of wild plants. - Annu. Rev. Ecol. Sys. 11: 233-260.

Chapin, F. S. III, Moilanen, L. and Kielland, K. 1993. Preferential use of organic nitrogen for growth by a nonmycorrhizal arctic sedge. - Nature 361: 150-153.

de Mazancourt, C. and Loreau, M. 2000. Effect of herbivory and plant species replacement on primary production. - Am. Nat. 155: 735-754.

de Mazancourt, C., Loreau, M. and Abbadie, L. 1998. Grazing optimization and nutrient cycling: when do herbivores enhance plant production? - Ecology 79: 2242-2252.

Eno, C. F. 1960. Nitrate production in the field by incubating the soil in polyethylene bags. - Soil Sci. Soc. Am. Proc. 24: 277-279.

Frank, D. A. and McNaughton, S. J. 1993. Evidence for the promotion of aboveground grassland production by native large herbivores in Yellowstone National Park. - Oecologia 96: $157-161$.

Franzluebbers, A. J., Stuedemann, J. A., Schomberg, H. H. et al. 2000. Soil organic $C$ and $N$ pools under long-term pasture management in the Southern Piedmont USA. - Soil Biol. Biochem. 32: 469-478.

Grellmann, D. 2002. Plant responses to fertilization and exclusion of grazers in an arctic tundra heath. - Oikos 98: 190-204.

Hobbs, N. T. 1996. Modification of ecosystems by ungulates. - J. Wildl. Manage. 60: 695-713.

Hobbie, S. E. 1992. Effects of plant species on nutrient cycling. - Trends Ecol. Evol. 7: 336-339.

Kielland, K. 1994. Amino acid-absorption by arctic plantsimplications for plant nutrition and nitrogen cycling. - Ecology 75: 2373-2383.
Kielland, K. and Bryant, J. P. 1998. Moose herbivory in taiga: effects on biogeochemistry and vegetation dynamics in primary succession. - Oikos 82: 377-383.

Kielland, K., Bryant, J. P. and Ruess, R. W. 1997. Moose herbivory and carbon turnover of early successional stands in interior Alaska. - Oikos 80: 25-30.

Knapp, A. K. and Seastedt, T. R. 1986. Detritus limits productivity in tallgrass prairie. - Bioscience 36: 662-668.

Kryazhimskii, F. V. and Danilov, A. N. 2000. Reindeer in tundra ecosystems: the challenges of understanding system complexity. - Polar Res. 19: 107-110.

Loreau, M. 1995. Consumers as maximizers of matter and energy flow in ecosystems. - Am. Nat. 145: 22-42.

McInnes, P. F., Naiman, R. J., Pastor, J. et al. 1992. Effects of moose browsing on vegetation and litter of the boreal forest, Isle Royale, Michigan, USA. - Ecology 73: 2059-2075.

McNaughton, S. J. 1979. Grazing as an optimization process: grass-ungulate relationships in the Serengeti. - Am. Nat. 113: $691-703$.

Milchunas, D. G. and Laurenroth, W. K. 1993. Quantitative effects of grazing on vegetation and soils over a global range of environments. - Ecol. Monogr. 63: 327-366.

Molvar, E. M., Bowyer, R. T. and Van Ballenberghe, V. 1993. Moose herbivory, browse quality and nutrient cycling in an Alaskan treeline community. - Oecologia 94: 472-479.

Oksanen, L. 1974. Kesä-ja talvilaidunnuksen vaikutuksesta jäkäläkankaiden kasvillisuuteen Finnmarksviddan pohjoisella tunturiylängöllä (in Finnish). Master Thesis.

Oksanen, L. 1978. Lichen grounds of Finnmarksvidda, Northern Norway, in relation to summer-and winter grazing by reindeer. - Rep. Kevo Sub-arctic Res. Stn 14: 64-71.

Oksanen, L. and Virtanen, R. 1995. Topographic, altitudinal and regional patterns in continental and sub-oceanic heath vegetation of northern Fennoscandia. - Acta Bot. Fenn. 153: $1-80$.

Olofsson, J. and Oksanen, L. 2002. Role of litter decomposition for the increased primary production in areas heavily grazed by reindeer, a litterbag experiment. - Oikos 96: 507-515.

Olofsson, J., Kitti, H., Rautiainen, P. et al. 2001. Effects of summer grazing by reindeer on composition of vegetation, productivity and nitrogen cycling. - Ecography 24: 13-24.

Pandey, C. B. and Singh, J. S. 1992. Rainfall and grazing effects on net primary productivity in a tropical savanna, India. - Ecology 73: 2007-2021.

Pastor, J. and Naiman, R. J. 1992. Selective foraging and ecosystem processes in boreal forests. - Am. Nat. 139: 690705.

Pastor, J., Dewey, B., Naiman, R. J. et al. 1993. Moose browsing and soil fertility in the boreal forests of Isle Royale National Park. - Ecology 74: 467-480.

Ritchie, M. E., Tilman, D. J. and Knops, M. H. 1998. Herbivore effects on plant and nitrogen dynamics in oak savanna. - Ecology 79: 165-177.

Schmidt, I. K., Jonasson, S., Shaver, G. R. et al. 2002. Mineralization and distribution of nutrients in plants and microbes in four arctic ecosystems: responses to warming. - Plant Soil 242: 93-106.

Shaver, G. R., Bret-Harte, M. S., Jones, M. H. et al. 2001. Species composition interacts with fertilizer to control longterm change in tundra productivity. - Ecology 82: 31633181 .

Sirotnak, J. M. and Huntly, N. J. 2000. Direct and indirect effects of herbivores on nitrogen dynamics: voles in riparian areas. - Ecology 81: 78-87.

Stark, S. and Grellmann, D. 2002. Soil microbial responses to mammalian herbivory in an arctic tundra heath at two levels of nutrient availability. - Ecology 83: 2736-2744.

Stark, S., Strömmer, R. and Tuomi, J. 2002. Reindeer grazing and soil microbial processes in sub-oceanic and subcontinental tundra heaths. - Oikos 97: 69-78.

Van der Wal, R. and Brooker, R. W. 2004. Herbivore impact on soil temperature and the abundance of grasses in tundra ecosystems. - Funct. Ecol., in press. 
Van der Wal, R., Bardgett, R. D., Harrison, K. A. et al. 2004. Vertebrate herbivores and ecosystem control: cascading effects of faeces on tundra ecosystems. - Ecography, in press.

Vitousek, P. M. and Howarth, R. W. 1991. Nitrogen limitation on land and in the sea: how can it occur? - Biogeochemistry 13: $87-115$.

Wardle, D. A., Barker, G. M., Yeates, G. W. et al. 2001. Introduced browsing mammals in New Zealand natural forests: aboveground and belowground consequences. - Ecol. Monogr. 71: 587-614.

Williams, B. L., Shand, C. A., Hill, M. et al. 1995. A procedure for the simultaneous oxidation of total soluble $\mathrm{N}$ and $\mathrm{P}$ in extracts of fresh and fumigated soils and litters. - Com. Soil Sci. Plant Anal. 26: (1\&2).

Zimov, S. A., Chuprynin, V. I., Oreshko, F. S. et al. 1995. Steppe-tundra transition: a herbivore-driven biome shift at the end of the Pleistocene. - Am. Nat. 146: 765-794. 